\title{
Pengaturan Sirkulasi Stasiun Sudirman dengan Konsep Flow
}

\author{
Debrilian Easther Magdalena dan Defry Agatha Ardianta \\ Departemen Arsitektur, Fakultas Teknik Sipil dan Perencanaan, Institut Teknologi Sepuluh Nopember (ITS) \\ e-mail: agathadefry@gmail.com
}

\begin{abstract}
Abstrak-Ruang publik merupakan sebuah ruang bagi warga untuk melakukan interaksi sosial yang harus dimiliki setiap kota yang secara tidak langsung menjadi cermin akan kualitas dari kota itu sendiri. Kota Jakarta dikenal dengan kepadatan penduduk dan mobilitas penduduk yang tinggi dengan penggunaan transportasi kereta sebagai transportasi utama warga kota Jakarta. Stasiun Sudirman adalah salah satu contoh ruang publik tempat meraih penggunaan jasa transportasi commuter-line untuk berpindah tempat sesuai tujuannya. Namun kualitasnya sebagai ruang publik menurun karena kepadatan sirkulasi pengguna dan fasilitas didalamnya yang kurang menarik. Artikel ini akan membahas tentang penerapan konsep flow melakukan redesain terhadap kualitas sirkulasi di Stasiun Sudirman Jakarta denngan tujuan untuk menjawab permasalahan stasiun dengan membuat alur sirkulasi yang terusmenerus dan menghasilkan interaksi antar pengguna, bangunan, dan sekitar.
\end{abstract}

Kata Kunci-flow, ruang pubik, sirkulasi, Stasiun Sudirman.

\section{PENDAHULUAN}

$\mathrm{S}_{\mathrm{p}}^{\mathrm{E}}$ ETIAP harinya manusia melakukan mobilitas, yaitu pergerakan berpindah tempat, dan berjumpa dengan orang yang berbeda-beda asal, tujuan, dan kebutuhan menurut bagaimana pergerakan setiap individu. Aktivitas manusia yang cukup padat seimbang dengan mobilitasnya yang tinggi sehingga kerap membuat setiap warga hanya menjalankan rutinitas pekerjaannya setiap hari tanpa ada interaksi dengan warga lainnya. Kebutuhan akan sebuah ruang publik yang sesuai dengan gaya hidup warga kota Jakarta menjadi isu yang harus diselesaikan dengan arsitektur.

\section{A. Stasiun Sudirman Jakarta}

Stasiun Sudirman merupakan salah satu contoh ruang publik kota yang tidak pernah sepi pengguna, berlokasi di Jalan Kendal, Menteng, Jakarta Pusat, berada di pinggir Sungai Ciliwung, daerah perkantoran, dan di pusat kota. Warga kota banyak memulai aktivitas hariannya pada stasiun ini dengan pergerakan yang serba cepat dan tak jarang berusaha untuk mencukupi kebutuhan seperti pangan pada fasilitas yang ada di stasiun ini saat jam pulang kerja. Namun fenomena yang terjadi, pengguna kerap mengalami kesulitan untuk memenuhi kebutuhannya karena kepadatan pengguna yang terjadi setiap jam pulang kerja, sehingga pergerakan pengguna terbatas yang berdampak pada kebutuhan untuk berinteraksi antar sesama pengguna, bangunan, dan sekitar. Stasiun Sudirman berpotensi menjadi ruang publik yang multifungsi seperti isi yang sudah ada yaitu fungsi stasiun beserta operasionalnya dan fungsi komersil, ditambah dengan lokasinya yang berada di pinggir sungai menjadi nilai yang harus dikembangkan sebagai ciri khas stasiun yang berbeda dari stasiun kereta di Jakarta pada umumnya.

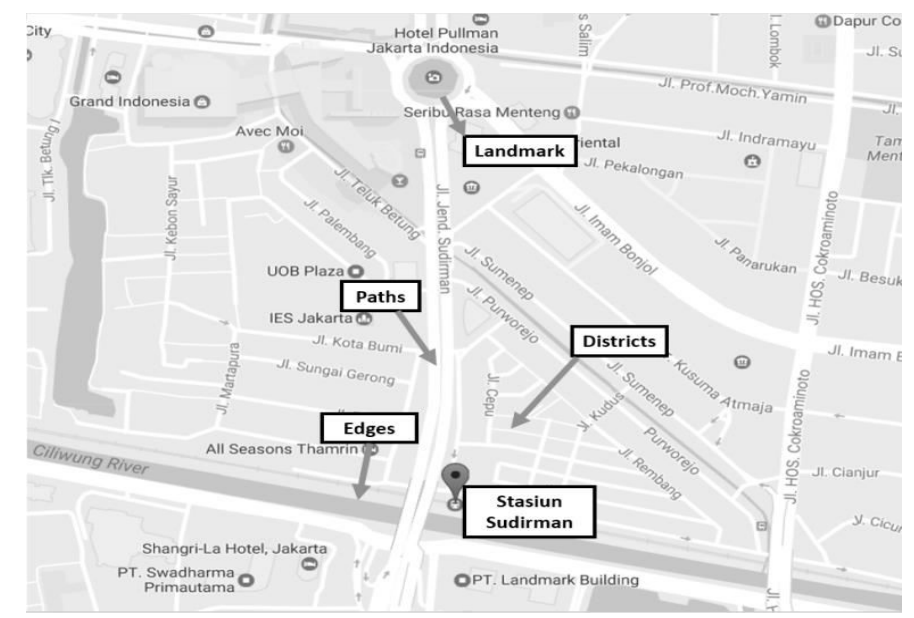

Gambar 1. Lokasi Stasiun Sudirman Jakarta.

\section{B. Gagasan Solusi dan Kriteria Desain}

Kualitas ruang publik dapat mempengaruhi kualitas sebuah kota, khususnya kota Jakarta, sehingga kebutuhan ruang publik sangat diperlukan dengan melihat sisi mobilitas masyarakat yang tinggi dimana tempat untuk beraktivitas dan bertemu terjadi saat penggunaan transportasi kereta. Oleh karena itu, obyek yang paling cocok untuk merespon isu tersebut adalah redesain stasiun kereta sebagai ruang publik yang dapat mewadahi kebutuhan masyarakat dengan pengaturan sirkulasi yang baik dan stasiun kereta yang dipilih adalah Stasiun Sudirman Jakarta.

\section{METODE PERANCANGAN}

\section{A. Pendekakatan The Physical Environment}

"Space as a Relationship between the Physical Surroundings and The Person who Perceives"'-Kevin Lynch, Lynch mengidentifikasi lima jenis elemen dibangun lingkungan yang mampu mempengaruhi bagaimana pengalaman orang dan mengevaluasi lingkungan mereka: landmarks, paths, districts, edges and nodes [1]. Pendekatan ini membantu melihat permasalahan arsitektural pada ruang publik terkait Stasiun Sudirman yang kemudia diaplikasikan dalam rancangan yang dapat membantu suasana lingkungan yang tercipta menjadi lingkungan yang ramah akan pengguna sebagai ruang publik yang baik dan terhubung dengan lahan sekitar bangunan (Gambar 1). 


\section{B. Metode Diagrammatic Method}

Diagrammatic Method adalah sebuah metode untuk mendata, menjadwal, dan menganalisa kegiatan atau aktivitas dalam sebuah rencana proyek berdasarkan hasil survey atau berangkat dari fenomena yang ada yaitu aliran sirkulasi manusia [2]. Aktivitas yang mungkin terjadi pada Stasiun Sudirman adalah bersimpangan karena berhenti sementara (Gambar 2), beralih (Gambar 3), dan menunggu (Gambar 4). Metode ini membangun sebuah diagram dari titik, simpul, atau kotak untuk mewakili kegiatan kemudian dihubungkan atau digabungkan yang menghasilkan sebuah area intensif (Gambar 5). Metode ini bertujuan untuk memperlihatkan serta mengevaluasi bagaimana hubungan aktivitas-aktivitas satu sama lain bersimpangan, kemudian memprediksi kemungkinan yang akan terjadi dimasa depan sehingga muncul gagasan untuk melakukan perbesaran pada daerah tersebut.


Gambar 2. Diagram Pengguna sedang Berhenti Sementara.
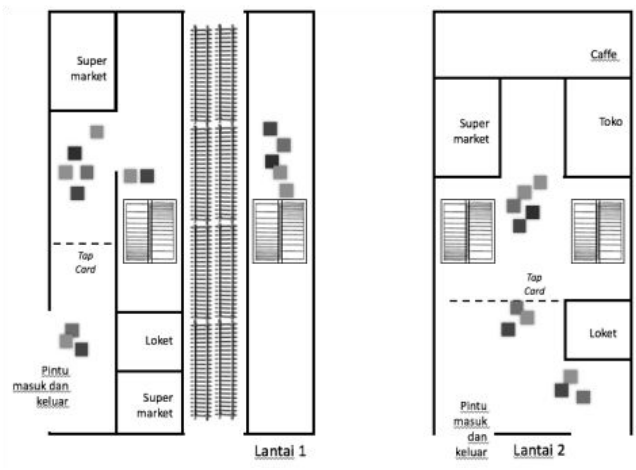

Gambar 3. Diagram Pengguna sedang Beralih.
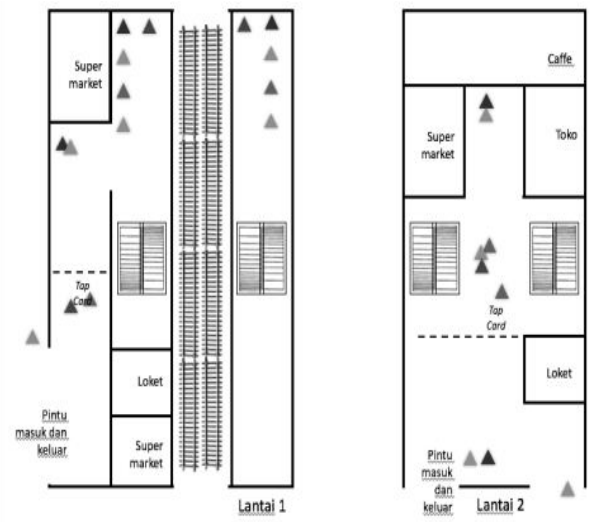

Gambar 4. Diagram Pengguna sedang Menunggu.
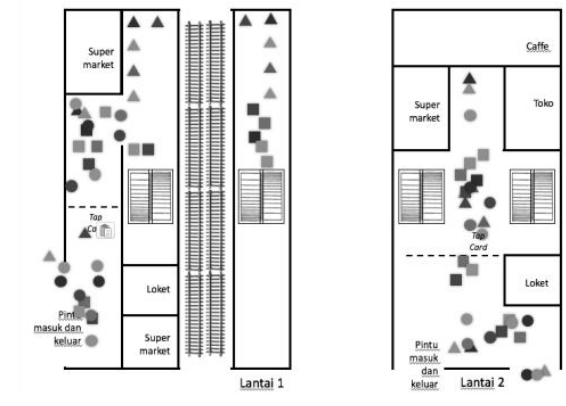

Keterangan aktivitas

Keterangan warna

- = Berhenti Sementara

- $=$ Re-direction

$\boldsymbol{\Delta}$ = Menunggu

- = Pegawai

- Ibu Rumah Tangga

= Lansia

- Disabilitas

Gambar 5. Gabungan Diagram Pergerakkan Pengguna.

\section{EKSPLORASI KONSEP DAN HASIL}

Konsep flow diambil dari folding architecture dipakai sebagai konsep keseluruhan dalam mendesain ulang bangunan stasiun dengan 4 poin utama seperti dibawah ini [3].

\section{A. Continuity}

Memiliki arti "mempertahankan konsistensi" atau mempertahankan suatu kondisi tertentu seperti elemen-elemen arsitektural yang ada dan memperhatikan konsistensi karakter ruang melalui saling terhubungnya ruang secara langsung, tidak lagi dibatasi oleh dinding maupun partisi, dan fungsi peron pada stasiun tetap dipertahankan.

\section{B. Connectivity}

Konektivitas atau menjalin hubungan dapat berupa hubungan antara manusia dengan bangunan, manusia dengan elemen-elemen perancangan, manusia dengan tapak, manusia dengan event, bangunan dengan event, bangunan dengan tapak atau manipulasi permukaan. Selain fungsi kereta, stasiun memiliki fasilitas lain yang dalam gagasan ini semua fasilitas diletakkan pada lantai yang berbeda (Gambar 6), sehingga bangunan stasiun terlihat seperti diangkat, diberikan akses mengalir untuk setiap lantainya, dan lahan pinggir sungai digunakan sebagai akses penghubung pengguna ke jembatan Thamrin. (Gambar 7).

\section{Loop}

Merupakan suatu konsep sirkulasi menerus tanpa jalan buntu, putaran, dan titik balik yang diciptakan secara menerus tanpa ada titik awal dan akhir selain itu, permukaan lantai juga dapat digunakan untuk menghubungkan antar level bangunan (Gambar 8), dan harus menggambarkan kejelasan arah atau orientasi yang memudahkan untuk bersirkulasi (Gambar 9). Loop bertujuan untuk menciptakan sirkulasi yang terus menerus untuk mengurangi kepadatan pengguna di titik-titik Intensive Space. 

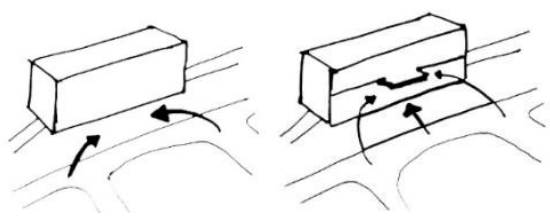

Gambar 6. Ilustrasi Continuity dan Connectivity.
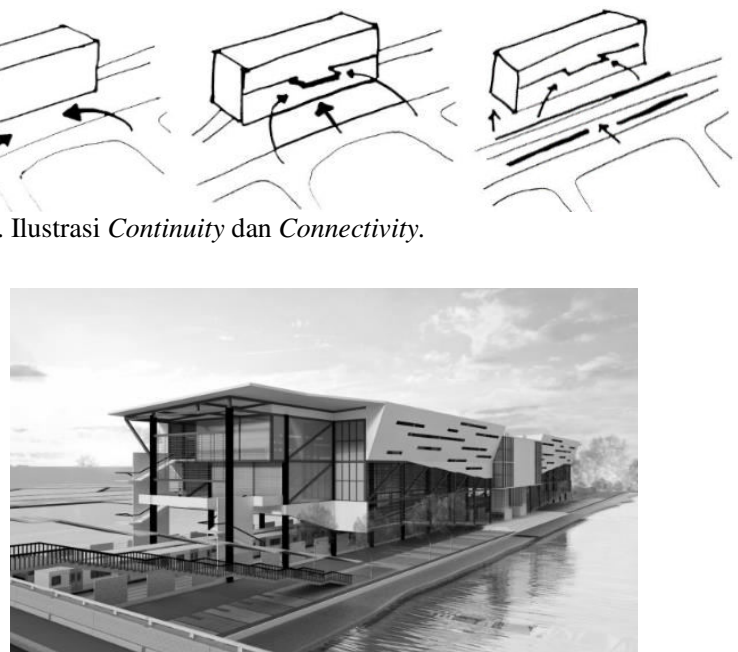

Gambar 7. Perspektif Eksterior Mata Normal Stasiun Sudirman.

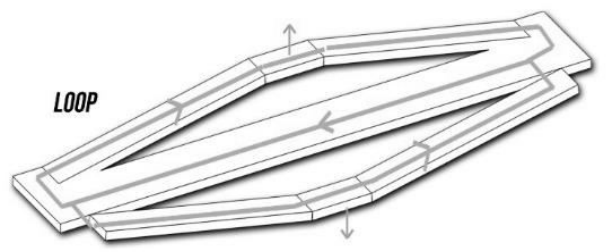

Gambar 8. Ilustrasi Sirkulasi Loop.

\section{Oblique Ground}

Lantai yang memiliki kemiringan, memiliki fungsi untuk menciptakan konektivitas antar level bangunan yang masih memungkinkannya diinjeksikan fungsi, bukan hanya sebuah elemen sirkulasi, dan memiliki peranan untuk menghilangkan kesan langsung. Oblique ground memiliki potensi memberikan kesan fluid dan dinamis secara visual, sehingga kemiringan lantai tersebut biasanya di tampilkan apa adanya tanpa dilakukan pembungkusan lebih lanjut oleh façade. Standarisasi dari Oblique Ground atau lantai yang memiliki kemiringan landai seperti 5 hingga 8 derajat berupa ramp (Gambar 10). Injeksi fungsi diciptakan dengan membuat banyak bordes untuk keperluan seperti area duduk, vending machine, photobooth dan booth retail atau acara (Gambar 11).

\section{KESIMPULAN}

Stasiun Sudirman dinilai memiliki potensi lebih untuk

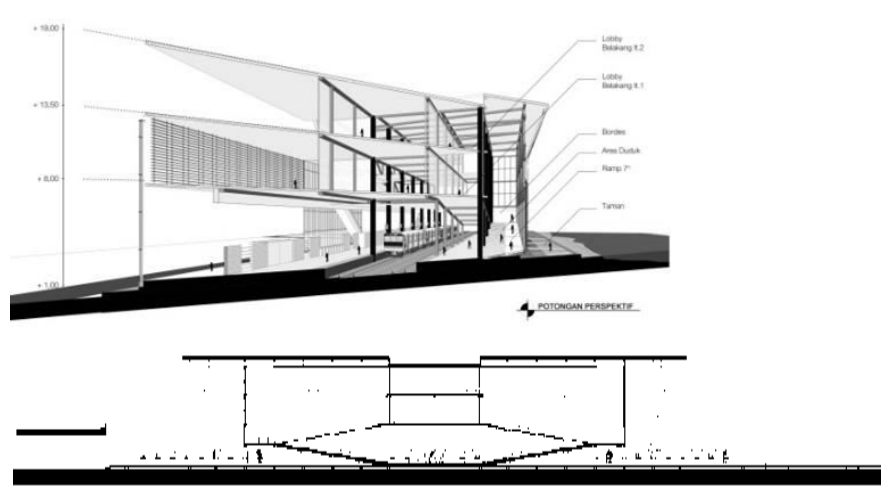

Gambar 9. Potongan Perspektif dan Potongan A-A.

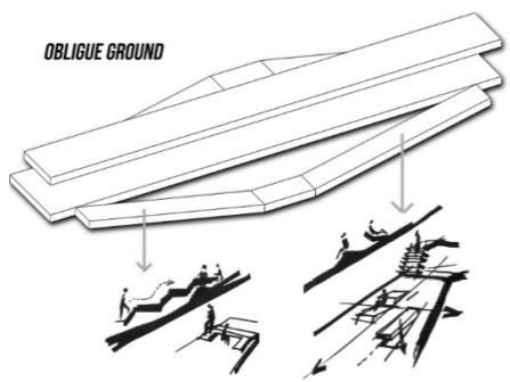

Gambar 10. Ilustrasi Oblique Ground.

menjadi sebuah ruang publik yang multifungsi, namun kepadatan sirkulasi membuat pergerakkan pengguna terbatas untuk memenuhi kebutuhan dan menikmati stasiun sebagai ruang publik. Konsep flow dipakai sebagai konsep keseluruhan gagasan redesain stasiun yang baik untuk bentuk bangunan dan mengatur sirkulasi didalamnya dengan melakukan perbesaran volume bangunan. Ruang gerak pengguna diperluas dengan adanya penambahan fungsi yang ditambahkan sehingga pengguna bisa saling melakukan interaksi dan mencukupi kebutuhannya dengan nyaman.

\section{DAFTAR PUSTAKA}

[1] K. Lynch, The Image of the City. Cambridge, Massachusetts: MIT Press, 1960.

[2] Wikipedia, "Precedence Diagram Method," 2016. [Online]. Available: https://en.wikipedia.org/wiki/Precedence_diagram_method.

[3] A. Nadia, "Arsitektur Folding sebagai Suatu Metode dalam Perancangan Arsitektur," Bandung, 2009. 